\title{
Storm in the Air: The Battle Over the 1992 Cable Act
}

\author{
Samuel B. Hoff \\ Delaware State University, USA
}

\begin{abstract}
Utilizing primary documents available at the George Bush Presidential Library, this study evaluates the veto record of President Bush using a case study as well as quantitative methods. The case study reviews the background and fate of the only veto overridden during his term in office. It finds that the Bush White House had tried on several previous occasions to scrap the legislation, only to have it be reintroduced in each succeeding Congress. By 1992, when George Bush was running for reelection and in trouble politically, his team was unable to stave off defeat. The article likewise assesses the success of the Bush administration in its employment of the veto and compares the veto record of President Bush to previous and subsequent chief executives.
\end{abstract}

Keywords: Veto, override, president, Congress, cable regulation, 1992 Cable Act

\section{Introduction}

The election of George Bush as president in 1988 signaled a continuance of Republican party control of the White House, a conservative approach to political issues, and the perpetuation of divided party government. Ronald Reagan had confronted a split or hostile party Congress throughout his presidency. No two consecutively elected presidents had faced such an obstacle. However, there was little reason to believe that George Bush would be constrained by the legislative process. As a former diplomat, national party chief, and head of the intelligence community, he had been well-versed in the tactics of negotiation and compromise; as the incumbent vice president, he had numerous allies in Congress to rely on. So, George Bush entered the presidency with the promise of resolving problems in social and economic affairs, together with the maturity to tackle foreign policy crises.

But it soon became apparent that the Bush White House would have to play both offense and defense and utilize all the tools of the presidential office. President Bush employed the veto adeptly, suffering an override on only one public bill he negated - the last one, the Cable Act of 1992. This objective of this study is to present a case study of the passage of the aforementioned law within the context of the president's veto power. To accomplish that purpose, we will probe President Bush's approach to Congress, analyze the administration's overall veto strategy, examine President Bush's use of regular vetoes of public bills, delineate the background of cable television regulation, present the debate over the Cable Act of 1992 and trace the process by which the act was passed, vetoed, and overridden, compare President Bush's veto record to that of other chief executives, and evaluate the record of America's forty-first president.

Samuel B. Hoff, Dept. of History Ph.D./George Washington Distinguished Professor of History and Political Science and Law Studies Director, Delaware State University. 


\section{Bush's Approach to Congress}

Like his predecessor, George Bush's approach to the legislature was a product of many factors. In a 1989 study assessing his character, Freedman finds that Bush (p. 14) "has operated as a cautious, accommodating man, avoiding taking stands and joining battle, gamely, bravely, doing the job assigned to him," and that his "strength has been in personal relations rather than in rhetoric or homework" (p. 22). Schwerzler (1990, p. 4E) claims that "The Bush administration has been willing to get involved with legislation early in the process on Capitol Hill, and Mr. Bush's personal contacts with legislators give him an advantage in sounding out their mood and helping to avoid unpleasant surprises." Sinclair (1990, p. 19) contends that a "combination of cooperation, conflict, and compromise that, in varying proportions, has characterized relations between Bush and the Democratic-controlled Congress on most issues..." Rose refers to Bush's tendency to make consensus a criteria for commitment as a "no-lose" philosophy (1991, p. 310).

Malecha and Reagan (1992a, p. 13) hold that President Bush's goal "was a relationship in which the members of the different branches of government subordinated partisan and institutional interests to the good of the whole." Sinclair (1991) describes Bush's performance over the first two years of his administration:

The record of Bush and 101st Congress in non-budget domestic policy probably delineates the possibilities, character, and limits of policy change under conditions of divided party control and no strong public demand for action. The policy preferences of president and congressional majority were probably as similar as they are likely to be under divided control. Nevertheless, on major legislation, policy differences were frequently very large, and budgetary stringency worked against the passage of major new legislation. The end result was a respectable but unheroic record. (p. 171)

During his final two years in office, President Bush faced both structural problems and a growing inability to subdue opposing political forces. Peele (1992, p. 154) postulates that "Bush initially may have though he could separate domestic and foreign policy concerns, but he was to learn rather painfully that the ability to act decisively abroad is dependent on the state of the economy at home." Peele identifies ensuing tactics used by Bush "that naturally suited his style of government, and, more cynically, fitted a situation in which federal resources were not available" (p. 155), including promoting some issues while negotiating on others. Malecha and Reagan (1992b, p. 14) state that although members of Congress initially applauded Bush's approach, "it is common today to hear of the disappointment and acrimony that mark his dealings with the legislative branch." Donovan (1992, p. 3452) decries that the "acid atmosphere and absence of federal funds left Congress and the White House to battle over limited policy agendas-issues on which ideology takes precedence and compromises are hard to reach."

Clymer (1992, p. A1) claims that the 102nd Congress was "notable for battles with President Bush when one side or the other claimed victory but national problems like the recession endured." Dewar (1992, p. A33) declares that "Over the two-year life of the 102nd Congress, lawmakers brought a heavy load of legislation on a wide variety of issues to the verge of enactment, only to be thwarted by Republican filibusters in the Senate or presidential vetoes that could not be overridden." Davis (1992) summarizes President Bush's legislative record below:

...Bush won a dismal 43.0 percent of the roll call votes on which he took a stand in 1992 . His score- 11 percentage points below his 1991 level — was the worst performance of any president at any point in his term since CQ began keeping score 39 years ago. For every vote taken during the four years, Bush won an average of 51.8 percent - the lowest of any firs term president since CQ began tracking this variable in 1953. 
Bush did even worse when measured against his own legislative priorities. None of the three major legislative requests he made in his state of the Union address - and economic package, school choice and a health care plan — became law. (p. 3841)

\section{Veto Strategy}

While not mentioning the veto by name, George Bush (New York Times, 1988, p. 8) pledged to oppose Congress when necessary in his acceptance speech as Republican presidential nominee, stating that "Congress will push me to raise taxes and I'll say no, and they'll push, and I'll say no, and they'll push again. And I'll say to them, read my lips, no new taxes." At a press conference marking the first anniversary of his election to the presidency, Bush fielded several questions about his domestic agenda. When asked what he would do differently if bipartisanship did not work, the president responded in the following manner (Weekly Compilation of Presidential Documents, 1989):

Exhort. What else can I do? Veto and exhort. Send stuff down I can't accept: it goes back. A President has to show that's his responsibility. (p. 1695)

Various authors have maintained that the Bush White House undertook a conscious veto plan. According to Walsh (1990), such a strategy was developed at the outset of Bush's term:

The Bush administration came into office with a sophisticated battle plan for using the President's naysaying power. Chief domestic advisor Roger Porter has spent years studying the veto as a Harvard political scientist. One of Porter's major beliefs was that the veto should not always be considered the end of a bill's evolution but only part of an ongoing process of compromise. (p. 18)

Walsh relays the view of a senior administration official regarding the role of the veto below:

The veto strategy lets us throw a monkey wrench into the Democrats' plans and keeps them from governing from the Hill. But over the long run, it really will not help us govern. (p. 20)

David Broder (1990, p. 8) quotes Chief of Staff John Sununu as asserting that President Bush will use a veto strategy "not to threaten, but to define guidelines as early in the process as possible, so that everyone understands the kind of bill he can sign." As the 101st Congress concluded, one study (Jones, 1991, p. 61) revealed that the "threat of vetoes for legislation carried over to the final weeks of the second session," while another (Hook, 1990, p. 2991) found that "the Bush administration has issued 120 veto threats since the beginning of 1989, and many are still outstanding on pending legislation." Rose (1991, p. 313) finds that "In his first two years in office, President Bush has successfully vetoed more legislation than any predecessor since President Ford."

During 1991 the president continued to rely on a veto strategy. Devroy (1991a, p. A1) notes that "White House spokesman Marlin Fitzwater signaled that the real thrust of domestic policy will be the same as it has been throughout Bush's presidency - the veto," and that the "White House has so perfected the art of the veto that is now has graduated categories of threat, ranging from the threat made by a single Cabinet member, to advice by 'senior advisors' to Bush, to veto statements by Bush himself" (Devroy, 1991b, p. A4). Ingwerson (1991, p. 8) notes that "Bush has been very clear from early in the drafting of legislation about what he would veto and why. He always follows through." Clymer (1991, p. 22) claims that the White House veto strategy "has dimmed the Democrat's self-image as the party that offers solutions."

Malecha and Reagan (1992b) observe the following concerning President Bush's veto employment: 


\begin{abstract}
Although most scholars of the presidency concede that reliance on veto power signifies weakness rather than strength, Bush has managed to earn respect for the "savvy" and "mastery" with which he has wielded that power...Bush's success in using the veto can be traced to his ability to cultivate an illusion of strength. (p. 65)
\end{abstract}

Eastland (1992, p. 73) determines that "Bush's veto power was respected on Capitol Hill, and his threats were influential." Fessler reveals the view of chief White House lobbyist Nicholas Calio, who emphasized that the administration was able to achieve many of its goals "by either vetoing bills it opposed or issuing veto threats that forced lawmakers to compromise" (p. 3249).

\title{
Regular Vetoes of Public Bills, 1989-1992
}

President Bush issued 29 regular vetoes by regular means over his presidency. In 1989, the president rejected nine public bills, including six of domestic content and three dealing with foreign affairs. Three of the domestic bills vetoed included abortion funding. Four of nine public bills went unchallenged; three were sustained by the House, and one by the Senate at the initial reconsideration stage; and one veto- the last of 1989, which concerned legislation permitting Chinese students to remain in the United States after their visas expired-was sustained by the second chamber. Bush's large number of first-year vetoes placed him in a three way tie among chief executives who have served over the last century (see Table 1). Since the mean frequency of first-year public bills vetoed by regular means from 1889 to 2009 is 2.3 (Hoff, 2012), Bush is far above average in his utilization of the veto at that juncture in his administration.

Table 1

First Year Public Bill Vetoes by Presidents, 1889-2009

\begin{tabular}{|l|l|l|}
\hline 1 & Ford (1974) & 14 \\
\hline 2 & F. Roosevelt (1937) & 9 \\
\hline 3 & Nixon (1973) & 9 \\
\hline 4 & Bush (1989) & $\mathbf{9}$ \\
\hline & Truman (1949) & 8 \\
\hline & F. Roosevelt (1941) & 6 \\
\hline 5 & Truman (1945) & 6 \\
\hline 6 & Reagan (1985) & 6 \\
\hline & Harding (1921) & 4 \\
\hline 7 & Kennedy (1961) & 3 \\
\hline 8 & L. Johnson (1965) & 3 \\
\hline & Carter (1977) & 2 \\
\hline & Eisenhower (1953) & 1 \\
\hline
\end{tabular}

In 1990, President Bush vetoed six public bills by regular means. Five bills pertained to domestic policy, whereas one dealt with foreign trade. All of Bush's vetoes were challenged by Congress. Three were sustained by the House and two by the Senate after initial reconsideration. The president's first veto of 1990-like the final one of 1989 - reached the second chamber.

During 1991, the Bush administration vetoed three public bills by regular means. All three pertained to domestic matter. One veto went unchallenged, while the remaining two were sustained by the first chamber to consider override.

In the final year of his presidency, George Bush vetoed 11 public bills by regular means, nine on domestic legislation and two against bills pertaining to foreign affairs. Of the 11 vetoes, two went unchallenged, four 
were sustained by at the initial chamber stage, four were overridden by the first house but sustained by the second chamber and one - the last public bill vetoed by regular means during the Bush administration-was overridden by both chambers. The 11 public bill vetoes constitute 38 percent of President Bush's total over his four years in office. In comparison, 37 percent of all public bill vetoes issued between 1889 and 1989 occurred in the final year of a chief executive's term (Hoff, 1991). While numerous, Bush's final-year total is not a record: Franklin Roosevelt vetoed 33 public bills in 1940; Gerald Ford rejected 17 public bills if 1979; and William Taft returned 16 public bills in 1912.

Among the subject matter of public bills vetoed by President Bush in 1992 were two bills dealing with most favored nation trading status for China, a tax bill, an appropriations bill for the District of Columbia, the motor-voter proposal, family leave and family planning legislation, a campaign finance bill, a Sioux Indian claims bill, and legislation proposing fetal tissue research. However, it was S. 12, proposing regulation of cable television, that led to Bush's only veto defeat.

\section{Background of Cable Regulation}

The Communications Act of 1934 was the initial law regulating aspects of communication which came to include cable television. By the early 1970's, it was apparent that changes were necessary. A 1972 agreement between the administration of President Richard M. Nixon, broadcasters, and the cable industry established rules overseeing cable competition, with the goal of protecting television networks and local broadcasters (Besen, 1974).

The first substantial amendments to the Communications Act of 1934 were made 50 years after its passage. The Cable Communications Policy Act of 1984 defined jurisdictional boundaries among federal, state, and local authorities, but had the main purpose of deregulating rates. The subsequent period of deregulation brought rapid growth in cable industry investments in programming and technology. From 1984 to 1990, the percentage of cable systems offering more than 30 channels increased from 38 to 67 percent (Boudreaux \& Ekelund, 2004).

Several problems with the 1984 cable legislation led to a movement to harness the industry. First, even as the number of cable providers and subscribers grew precipitously, competition lagged. Second, rates for service increased excessively, leading to a plethora of complaints by consumers. For instance, the average monthly rate for basic cable service increased by 61 percent between 1986 and 1991, according to the U.S. General Accounting Office (Boudreaux \& Ekelund, 2004).

\section{Battle Over Cable Act of 1992}

By the time George Bush took office as America's 41st president, the battle over control of cable rates was already well under way. By analyzing primary documents from the George Bush Presidential Library, we can discern just how heated the conflict was.

In 1989, legal and political issues surrounding the cable industry were already on the radar of the Bush White House. For instance, Federal Communications Commission Chair Alfred Sikes testified about cable television policies, recommendations, and initiatives to the U.S. Senate Subcommittee on Communications in November. Meanwhile, the municipalities of Boynton Beach, Florida (September), Highland Heights, Ohio (October), and Cleveland Heights, Ohio (November) transmitted resolutions from city councils advocating legislation to revise the 1984 Cable Act to President Bush, which were acknowledged by Special Assistant to the President for Intergovernmental Affairs. 
In 1990, FCC Chair Sikes gave remarks at the National Cable Television Association's annual meeting, in which he supported competitive markets in all communications milieus. In June of that year, Sikes wrote Bush White House Chief of Staff John Sununu to complain of a characterization of the FCC as "off the deregulation reservation." Sikes assured Sununu that the FCC was pro-competition and that its efforts at promoting deregulation were widely recognized. In a comprehensive report to Congress issued in July 1990, the FCC backed "limited, specifically targeted remedial measures" to address deficiencies in service, competition, and rate control.

By September 1990, the Bush White House was actively responding to congressional proposals for greater cable regulation. A September $10 \mathrm{draft}$ memorandum composed by the Legislative Reference Division included a warning to cosponsors of the Cable Television Consumer Protection and Competition Act of 1990: "If H.R. 5267 was presented to the President in its current form, his senior advisors would recommend a veto." Concurrently, the White House Economic Policy Council conducted a review of several bills intended to tighten Federal legislation governing the cable industry.

During 1991, the U.S. Senate became more concerned with complaints about the cable industry. Missouri Senator John Danforth sponsored S. 12, the Cable Television Consumer Protection Act of 1991. The Bush team responded with a letter to Danforth which contained a similar warning as that issued to House members the year before: senior advisors would recommend a veto unless changes were made.

The Senate largely ignored the veto threat. On January 31, 1992, the Senate passed the Cable Television Consumer Protection and Competition Act of 1992 by a 73 to 18 vote, with one senator voting present and eight not voting. The purpose of the bill was to amend "the Communications Act of 1934 to ensure carriage on cable television of local news and other programming and to restore the right of local regulatory authorities to regulate cable television rates..."

The Bush team then concentrated on stopping legislation from passing the House of Representatives. A March 31, 1992 White House memorandum from Phillip Brady to Nicholas Calio attached a draft letter of a veto threat to House leaders if the pending cable legislation was passed. That action was repeated on July 21 , with only the title of the legislation being different. Neither warning was heeded. On July 23, the House approved H.R. 4850, the Cable Television Consumer Protection and Competition Act of 1992, by voice vote.

Because the House and Senate versions of the cable legislation differed, a conference committee was created. On September 17, 1992, President Bush sent letters to House Speaker Thomas Foley and Senate Majority Leader George Mitchell directly warning a veto of S. 12. Usually, such a move was effective in facilitating changes favored by the White House. Not this time: the House approved the conference committee's compromise on S. 12 on September 17 by a $280-128$ vote, and the Senate backed the conference committee's version on September 22 by a $72-25$ tally.

Unquestionably, Congress' passage of cable reregulation was hastened by public pressure to get a handle on rates and to improve service. From February through September 1992, the Bush administration likewise felt the pressure through a series of letters urging the president not to veto cable industry reform.

Below is the list of municipalities and organizations which sent such letters to the White House:

- February 6, 1992: Town of Walpole, MA

- March 2, 1992: City of Friendswood, TX

- July 31, 1992: Wireless Cable Association, Inc. 
- August 4, 1992: The Capitol Connection at George Mason University,VA

- August 4, 1992: Television Viewers of America

- August 12, 1992: Marrco Communications, Inc., Newport Beach. CA

- August 27, 1992: City of Rock Hill, MO

- September 11, 1992: City of Olympia, WA

- September 14, 1992: Office of Attorney General, State of Connecticut

- September 24, 1992: City of Orangeburg, SC

- September 24, 1992: City of Pacifica, CA

- September 25, 1992: Anchor Media, St. Petersburg, FL

- September 26, 1992: City of Manitowoc, WS

- September 30, 1992: American Public Power Association, Washington, DC

- October 2, 1992: WAVA 105 FM, Arlington, VA

As the last of the latter letters reached the White House, the Office of Management and Budget issued its recommendation on the Cable Television Protection and Competition Act of 1992. In a September 25, 1992 memorandum to President Bush, OMB summarized the discussion over the legislation and agency recommendations by stating that "we join Commerce, Justice, the FCC, and the Office of Consumer Affairs in recommending disapproval of S. 12."

In his October 3 veto message, the president remarked that the cable bill (Weekly Compilation of Presidential Documents, 1992)

is clearly long on promises. Unfortunately, it is just as short on relief to the American families who are quite rightly concerned about significant increases in their cable rates and poor cable service... S. 12 tries to address legitimate consumer concerns, but it does so by requiring cable companies to bear the costs of meeting major new federally imposed regulatory requirements and by adopting costly special interest provisions. (p. 1860)

On October 5, the Senate voted to override the veto by a 74-25 vote, which matched the original Senate roll call on the legislation. During the override debate, Senate Minority Leader Robert Dole (Zaldivar, 1992, p. 1) asserted "This is an effort to embarrass the president; the merits of this legislation have been forgotten." According to Zaldivar, the vote "came despite two weeks of determined lobbying by the White House, with Mr. Bush personally appealing to the bill's Republican supporters to switch. None did" (p. 1). Hours later, the House overrode the veto by a 308-114 score, which was a significantly higher margin of support that the original 280-128 vote. Reporter Diane Duston (1992) described the scene below (1992):

Clapping, cheers, and hand-slapping erupted on the Democratic side of the House floor as the vote total neared the magic number of 289 , assuring the veto would be overridden. Democrats began changing, "Go, go, go" as the vote total crossed that number. (p. 1)

Duston holds that opponents of the legislation "blamed election-year politics for the override, but proponents said consumer anger over soaring rates let to wide bipartisan support for the measure" (p. 1). In an editorial following the override, the Baltimore Sun (1992) reflected on the meaning of the action:

In institutional terms, the veto override gives new meaning to Mr. Bush's jibes about a "gridlock Congress." His pen was half the problem; Democratic opposition to his programs was the other. The legislative branch, for all its faults, was the branch of government that finally, of only symbolically, broke the gridlock. You can be sure the next president will try to reimpose executive supremacy. (p. 26A) 


\section{Comparing Bush's Veto Record to Other Presidents}

President Bush's 29 public bill vetoes by regular means may be contrasted with other chief executives. On a per year basis, Bush vetoed an average of 7.25 bills, placing him third on annual veto use among president servicing since 1889. Only Gerald Ford (15.30) and Franklin Roosevelt (8.75) have a higher annual average of public bill vetoes by regular means (see Table 2). Galemore (1992) figures that "President Bush has vetoed about $2-3 \%$ of the bills presented to him by Congress, matching the average percentage of vetoes by all Presidents. He has been overridden on only one occasion...a better success record than most modern presidents" (p. 2). In fact, Bush's 75.9 sustain success percent at the first house juncture of reconsideration is lower than the average success rate of all other presidents over the last century (78.8 percent), although his second chamber sustain success percent-96.55-is substantially higher than the mean sustain success for all chief executives who faced second house votes from 1889 to 2009 (Hoff, 2012; see Table 4).

Table 2

Average Number of Annual Public Bill Vetoes by Presidents, 1889-2009

\begin{tabular}{|l|l|l|}
\hline 1 & Ford & 15.30 \\
\hline 2 & F. Roosevelt & 8.75 \\
\hline 3 & Bush & $\mathbf{7 . 2 5}$ \\
\hline $\mathbf{4}$ & Truman & 6.88 \\
\hline 5 & Taft & 5.50 \\
\hline 6 & Reagan & 4.63 \\
\hline 7 & Clinton & 4.50 \\
\hline 8 & Eisenhower & 4.38 \\
\hline 9 & Nixon & 4.00 \\
\hline 10 & Cleveland & 3.75 \\
\hline 11 & B. Harrison & 3.50 \\
\hline 12 & Hoover/Carter & 3.25 \\
\hline 13 & Wilson & 3.13 \\
\hline 14 & T. Roosevelt & 2.25 \\
\hline 15 & Coolidge & 2.20 \\
\hline 16 & Harding & 1.67 \\
\hline 17 & L. Johnson & 1.40 \\
\hline 18 & G.W. Bush & 1.38 \\
\hline 19 & Kennedy & 1.33 \\
\hline 20 & McKinley & .25 \\
\hline
\end{tabular}

Table 3

Pocket Veto Leaders, 1789-2009

\begin{tabular}{|l|l|l|}
\hline 1 & F. Roosevelt & 263 \\
\hline 2 & Cleveland (1st) & 128 \\
\hline 3 & Cleveland (2nd) & 110 \\
\hline 4 & Eisenhower & 108 \\
\hline 5 & Truman & 70 \\
\hline 6 & Grant & 48 \\
\hline 8 & Reagan & 39 \\
\hline 9 & McKinley & 36 \\
\hline 10 & Coolidge & 30 \\
\hline
\end{tabular}


Table 4

Presidential Success in Preventing Veto Overrides, 1889-2009

\begin{tabular}{llll}
\hline President & & \% of vetoes sustained* & Total veto overrides \\
\hline 1 & Bush & $\mathbf{9 6 . 5 5}$ & $\mathbf{1}$ \\
2 & Taft & 95.45 & 1 \\
3 & T. Roosevelt & 94.44 & 1 \\
& Clinton & 94.44 & 2 \\
4 & Eisenhower & 94.29 & 2 \\
5 & B. Harrison & 92.86 & 1 \\
6 & F. Roosevelt & 91.43 & 9 \\
7 & Cleveland (II) & 86.67 & $2 / 5^{* *}$ \\
8 & Carter & 84.62 & 2 \\
9 & Truman & 80.00 & $11 / 12^{* *}$ \\
10 & Hoover & 76.92 & 3 \\
11 & Wilson & 76.00 & 6 \\
12 & Reagan & 75.68 & 9 \\
13 & Ford & 73.91 & 12 \\
14 & Nixon & 70.83 & 7 \\
15 & Coolidge/G.W. Bush & 63.64 & 4 \\
16 & Four presidents with no overrides: McKinley, Harding, Kennedy, and L. Johnson
\end{tabular}

Notes. * refers to vetoes of public bills; ** Cleveland (II) had 3 private bill vetoes overridden; Truman had 1 private bill veto overridden.

Over his four years in office, President Bush pocket vetoed a total of 17 bills. Of these, all but one concerned domestic legislation, and all but one pertained to public bills. Bush's a total matches that of Richard Nixon, but does not place him among the top 10 chief executives in terms of pocket veto use (see Table 3). Bush's extensive application of the pocket veto in his final year of office is consistent with the findings of a recent study, which show that high unemployment *7.4 percent in 1992 and later years with chief executives' terms both significantly increase annual pocket veto frequency across the last century (Hoff, 1994).

A multitude of presidents since Ulysses Grant have favored an item veto - the power to delete, subject to congressional reconsideration, individual parts of legislation-including Franklin Roosevelt, Harry Truman, Dwight Eisenhower, Gerald Ford, and most recently Ronald Reagan. The Bush administration likewise supported the tool, and forwarded diverse ideas for achieving it. The president stated in July 1989 that he was not pushing for a constitutional amendment for a line-item veto because (Congressional Quarterly Weekly Report, 1989, p. 2848), "I think something like that could probably be done legislatively." Seib (1990) notes that in October 1989, the White House proclaimed that "Mr. Bush is considering simply declaring that the Constitution gives him the power, exercising a line-item veto and inviting a court challenge to decide whether he is right" (p. A12), a strategy contemplated by rejected by Reagan personnel (Rapp, 1988). In 1990, the Bush administration expressed willingness to consider tax increases at a May budget summit in exchange for a line-item veto power.

In lieu of an actual line item veto, President Bush employed presidential signing statement, a tactic whereby the chief executive presents his own view of the intent and meaning of a law. Devroy (1990) reports that the Bush government attached a three-page statement to legislation authorizing funding for the State Department, in which several of the law's stipulations were criticized. Crovitz (1990) claims that Bush used the devise to negate "41 provisions in some 20 bills that Congress passed" (p. A15) in 1990. 
In the ensuing presidential administration, the line item veto would be employed pursuant to a law, the Line Item Veto Act of 1996. However, the law was declared unconstitutional by the Supreme Court two years later, negating President Bill Clinton's utilization of the toll on 83 items in 11 spending bills (Hoff, 2003).

Several writers have witnessed a clear distinction in veto behavior between Presidents Ronald Reagan and George Bush. Former Republican congressman Lawrence DeNaris states (Schwerzler, 1990, p. 4E),

Clearly, Reagan and Bush take very different approaches to the veto...Reagan used the veto as an expression of his ideology. He'd take a stand on a variety of issues, whether he could sustain a veto or not.

Walsh delineates differences between Reagan and Bush veto Styles below (1990, p. 19):

As his administration wore on, he made the mistake of threatening more and more vetoes, then backing off without extracting important concessions from the Democrats. That damaged his credibility because his threats were not take seriously and his GOP allies were never sure whether he would change his mind. By contrast, Bush tries to avoid antagonizing large constituencies or inflaming congressional passions...

Hook (1990) holds that many lawmakers believed that President Reagan was strong on threatening vetoes but often failed to follow through, whereas President Bush "has made few empty veto threats and has picked his fights with care" (p. 2991). Eastland (1992) propagates that "in general, Reagan did not have as much credibility as Bush. For unlike Reagan, Bush used the veto in every instance in which his warnings did not result in change he could accept" (p. 73).

In comparing the veto record of George Bush with that of his son George W. Bush, Hoff (2012) observes that both presidents consistently defended a pro-life orientation. Conversely, the elder Bush vetoed more often and had more success in preventing overrides than his son, who suffered four veto overturns over his last two years in office.

\section{The Veto and the Bush Presidency}

Given the definition of gridlock offered at the outset of this study, it cannot be stated that George Bush experienced this condition throughout his term as president, or that the veto was the culprit in creating such a barrier to progress and cooperation. For one, Milius maintains that presidential congressional comity during the 101st Congress resulted in many important achievements. He (1992) finds that the "list of their accomplishments nonetheless gives the lie to those who see divided government as a formula for gridlock; you didn't hear the word then" (p. 12). Fessler (1992) details several notable victories by the Bush team:

His administration's support in 1989 help end a 13-year deadlock over legislation to impose stricter clean air standards. He compromised with Congress in 1990 - to his later chagrin - to achieve a long-term budget agreement that imposes some fiscal discipline over the following two years.

His success in winning congressional endorsement of an all-out war in the Persian Gulf helped solidify the 1991 international effort against Saddam Hussein. (p. 3247)

However, by late 1991, scholars and commentators alike began to perceive the ramifications of a growing stalemate between the branches of government. When Bush was as the height of his popularity in the Fall of 1991, Sidey (1991) warned that "George Bush may want to start looking around for a victory or two to throw the Democrats way lest he forget how lousy it feels to lose" (p. 27). According to Puerte (1992), "Political experts say veto politics is a key reason for the insurgent presidential candidacy of Ross Perot" (p. 4A). 
Burnham (1992) believes that "in the changed economic and political setting of 1992 [foreign policy and diplomacy skills] could not compensate for the image of distrust, punctuated by standpattism, that had grown up around him" (p. 32). For Milkis (2014), 1992 saw the implosion of the Bush administration's efforts to combine pragmatism with partisan leadership. In his 2014 portrait of his father, former President George W. Bush refers to 1992 as "the hardest year." According to the Center For Media and Public Affairs, 96 percent of TV evening news coverage of the economy between July and September 1992 was negative (Meacham, 2015).

Other criticisms of the Bush record clearly miss the mark. O'Sullivan (1992) accuses the administration of having a "blindness to ideology...The Bushmen thought of themselves as supreme pragmatists..." (p. 43). Yet, Bush was consistent in at least two areas of conservative political preference throughout his tenure: opposition to abortion, which he constantly used as justification to veto legislation which permitted liberalization of the procedure, and free trade policy, which is displayed in his vetoes of bills designed to punish China or limit textile imports.

Mullins and Wildavsky (1992) discover a "striking hierarchical pattern" (p. 35) in Bush's vetoes, suggesting that the president employed the tool effectively to defend "his party and his powers" (p. 36). Peele (1992) evaluates the forty-first chief executive's success in the following manner:

Ultimately, the Bush presidency has to be seen in the contest of a system that encourages deadlock in which the responsibilities of the chief executive are too great for any single individual. George Bush's mixed performance as president in the 1990's may deserve applause rather than condemnation. (p. 155)

George Bush lost his reelection bid in 1992 in part because the voters rejected the premise that conflict is better than nothing. Yet, the Democrat's electoral victory did not preclude the reemergence of gridlock, as was starkly demonstrated during the post-1994 Bill Clinton presidency. It is ironic that the veto-highly criticized by Clinton in his campaign against Bush - turned out to be the tool which got him off the mat and reestablished his authority following the turnover of both legislative chambers to the Republicans (Hoff, 2003).

We are left to ponder the impact of part and personality, of structure and style, and of institution and individual on the American presidency. George Bush, like his predecessors over two centuries, illustrated the boundaries and borderless potential of this unique office.

\section{References}

Alston, C. (1989). Bush tests his pocket-veto power. Congressional Quarterly Weekly Report, December 2, p. 3285.

Alston, C. (1990). Bush Crusades on many fronts to retake president's turf. Congressional Quarterly Weekly Report, February 3 , 291-295.

Boudreaux, D., \& Ekelund, R. (2004). Cable reregulation. The Cato Journal, 14, 1-16.

Broder, D. (1990). Veto strategy_And counters. News Journal, January 22, 9.

Burnhan, W. (1993). The legacy of George Bush: Travails of an understudy. In Pomper et al. (Eds.), The election of 1992: Reports and interpretations. Chatham: Chatham House Publishers.

Bush, G. W. (2014). 41: A portrait of my father. New York: Crown Publishers.

Clymer, A. (1992). The gridlock congress. New York Times, October 11, p. A1, 28.

Clymer, A. (1991). Win or Lose, Vetoes by Bush Frustrate Democrats. New York Times, September 29, p. 22 B.

Cronin, T. E., \& Weill, J. J. (1985). An item veto for the president? Congress and the Presidency, Autumn, pp. 127-151.

Crovitz, L. G. (1990). President Bush exercises the so-sue-me-line-item-veto. Wall Street Journal, November 21 , p. A15.

Davis, P. A. (1992). Politics, drop in senate support Puts Bush's ratings in cellar. Congressional Quarterly Weekly Report, December 19, pp. 3841-3843.

Devroy, A. (1990). Bush considers foreign policy lawsuit. Washington Post, February 17, p. A23. 
Devroy, A. (1991a). For Bush, a familiar pattern resumes: Agenda focuses overseas, not at home. Washington Post, June 9, p. A4-5.

Devroy, A. (1991b). Veto may remain Bush's key domestic policy tool. Washington Post, March 13, p. AI, 12.

Donovan, B. (1992). Partisanship, purse strings hobbled the 102nd. Congressional Quarterly Weekly Report, October 31, pp. 3451-3490.

Duston, D. (1992). Congress overrides cable veto. News Journal, October 6, p. 1.

Eastland, T. (1992). Energy in the executive: The Case for the strong presidency. New York: The Free Press.

Fessler, P. (1992). Bush's sway with congress hits record low in 1992. Congressional Quarterly Weekly Report, October 17, pp. 3247-3250.

Freedman, A. (1989). Predicting presidential performance: The character of George Bush. Unpublished manuscript.

Galemore, G. L. (1992). Presidential vetoes and the Bush administration. CRS Issue Brief. Washington: Congressional Research Service.

Hager, G. (1990). Bush's success rate sinks to near-record low. Congressional Quarterly Weekly Report, December 22, pp. 4183-4187.

Hoff, S. B. (2012). Back to basics: President George W. Bush and the veto power, 2001-2009. National Social Science Journal, 29-37.

Hoff, S. B. (2003). Evaluating the Clinton veto record, 1993-2001. National Social Science Journal, 38:2, 47-65.

Hoff, S. B. (1992). Presidential support, and veto overrides, 1889-1988. Midsouth Political Science Journal, Summer, pp. 173-189.

Hoff, S. B. (1991). Saying no: Presidential support and veto use, 1889-1989. American Politics Quarterly, July, pp. $310-323$.

Hoff, S. B. (1994). The presidential pocket veto: Its use and legality. Journal of Policy History, Spring, pp. 188-208.

Hook, J. (1990). Avalanche of veto threats divides Bush, congress. Congressional Quarterly Weekly Report, September 22, pp. 2991-2994.

Hook, J. (1989). Bush inspires frail support for first-year president. Congressional Quarterly Weekly Report, December 30, pp. 3540-3547.

Ingwerson, M. (1991). Why Bush is successful at sustaining vetoes. Christian Science Monitor, November 26, p. 8.

Jones, C. O. (1991). Measuring low expectations: Strategy and prospects of the Bush presidency. In Campbell and Rockman (Eds.), The Bush presidency: First appraisals. Chatham: Chatham House Publishers.

Malecha, G. L., \& Reagan, D. J. (1992a). Dilemmas of congressional leadership in the Bush administration. Paper presented at the 1992 Annual Meeting of the Southwestern Political Science Association, Austin, TX, March 18-21.

Malecha, G. L., \& Reagan, D. J. (1992b). George Bush and congress: The questions of leadership. In Barilleaux and Stuckey (Eds.), Leadership and the Bush presidency: Prudence or drift in an era of change? Westport: Praeger.

Meacham, J. (2015). Destiny and power: The American Odyssey of George Herbert Walker Bush. New York: Random House.

Milius, P. (1992). The two Bush administrations. Washington Post, November 15, p. 12.

Milkis, S. (2014). Conclusion: Navigating the crosswinds of modern politics and policy. In M. Nelson and B. Perry (Eds.), 41: Inside the presidency of George H. W. Bush. Ithaca: Cornell University Press.

Mullins, K., \& A. Wildavsky. (1992). The procedural presidency of George Bush. Political Science Quarterly, 107:1, 31-62.

O’Sullivan, J. (1992). Why Bush lost. National Review, November 30, pp. 30-44.

Peele, G. (1992). The constrained presidency of George Bush. Current History, April, pp. 151-155.

Puente, M. (1992). Unblemished veto record may haunt Bush. USA Today, June 22, p. 4A.

Rapp, D. (1988). Does Reagan already have a line-item veto? Congressional Quarterly Weekly Report, May 14, pp. 1284-1285.

Rose, R. (1991). The postmodern president: George Bush meets the world. Chatham: Chatham House Publishers.

Schwerzler, N. J. (1990). Bush keeps veto win streak going, but may face future trouble. Baltimore Sun, October 28, p. 4E.

Seib, G. F. (1989). If Bush tests constitutionality of line item veto, reverberations could transform government. Wall Street Journal, October 30, p. A12.

Sidey, H. (1991). You shouldn’t win ‘Em All. Time, October 28, p. 27.

Sinclair, B. (1991). Governing unheroically (and sometimes unappetizingly): Bush and the 101st congress. In Campbell and Rockman (Eds.), The Bush presidency: First appraisals. Chatham: Chatham House Publishers.

Sinclair, B. (1990). Hard choices, divided control, and incentives to leadership: Presidential congressional relations in the 1980's and 1990's. Paper presented at the 1990 Annual Meeting of the American Political Science Association, San Francisco, CA, August 30-September 2. 
Spitzer, R. J. (1991). Presidential prerogative power: The case of the bush administration and legislative powers. PS: Political Science and Politics, March, pp. 38-42.

The President Loses One. (1992). Baltimore Sun, October 7, p. 26A.

Transcript of Bush Acceptance Speech Accepting Presidential Nomination. (1988). New York Times, August 19, p. 8.

Walsh, K.T. (1990). Bush's veto strategy. U.S. News and World Report, July 2, pp. 18-20.

Zaldivar, R. A. (1992). Senate votes override cable TV veto. Baltimore Sun, October 6, p. 1, 9A. 